\title{
DESICCATION-INDUCED VOLUMETRIC SHRINKAGE OF COMPACTED METAKAOLIN-TREATED BLACK COTTON SOIL FOR A HYDRAULIC BARRIERS SYSTEM
}

\author{
George MOSES*1, Oriola F. O. PETER ${ }^{2}$, Kolawole J. OSINUBI ${ }^{3}$
}

\begin{abstract}
Black cotton soil treated with up to $24 \%$ metakaolin (MCL) content was prepared by molding water contents of $-2,0,2,4$ and $6 \%$ of optimum moisture content (OMC) and compacted with British Standard Light (BSL) and West African Standard (WAS) or 'Intermediate' energies. The specimens were extruded from the compaction molds and allowed to air dry in a laboratory in order to assess the effect of desiccation-induced shrinkage on the compacted mix for use as a hydraulic barrier in a waste containment application. The results recorded show that the volumetric shrinkage strain (VSS) values were large within the first 10 days of drying; the VSS values increased with a higher molding of the water content, relative to the OMC. The VSS generally increased with a higher initial degree of saturation for the two compactive efforts, irrespective of the level of MCL treatment. Generally, the VSS decreased with an increasing MCL content. Only specimens treated with a minimum $20 \% \mathrm{MCL}$ content and compacted with the WAS energy satisfied the regulatory maximum VSS of $4 \%$ for use as a hydraulic barrier.
\end{abstract}

Address

1,2 Department of Civil Engineering, Nigerian Defence Academy, Kaduna, Nigeria

3 Department of Civil Engineering, Ahmadu Bello University Kaduna, Zaria.

* Corresponding author: mgeorge@nda.edu.ng

\section{Key words}

- Black cotton soil,

- Compactive effort,

- Desiccation,

- Metakaolin,

- Volumetric shrinkage strain.

\section{INTRODUCTION}

The study of desiccation-induced shrinkage of hydraulic barrier material is very important in the design of liner systems. This is because excessive volume changes under varying extreme weather conditions (from dry to wet seasons) lead to cracks being generated, which can result in a geometric increase in the hydraulic conductivity values. An increase in the hydraulic conductivity value beyond the permissible limit of greater than $10^{-9} \mathrm{~m} / \mathrm{s}$ leads to permeant liquid passing through the cracks generated. Failure of the liner system becomes inevitable, as the strength of the cracked soils decreases, while there an increased flow of contaminants through the soils into the ground.

Researchers such as Daniel and Wu (1993), Albrecht and Benson (2001), Osinubi and Nwaiwu (2005, 2008), and Osinubi and Eberemu, $(2006,2009)$ suggested that a specimen compacted at a greater molding water content shrank more during drying. Daniel and $\mathrm{Wu}$ (1993) and Tay et al. (2001) suggested that cracking is not likely to occur in soil liners when compacted cylinders of the same soil undergo less than about a $4 \%$ volumetric shrinkage strain upon drying. Other materials used as liners or covers in waste containment systems, in addition to natural clayey soils, include processed clay/ sand-processed clay mixtures, geosynthetic materials and industrial waste products (Bowders et al., 1987; Abichou et al., 2000; Albrecht and Benson, 2001). Furthermore, studies have been carried out on the use of compacted lateritic soil as liners and covers in waste containment applications (Osinubi and Nwaiwu, 2005, 2006; Osinubi and Eberemu, 2006; Osinubi and Amadi, 2009; Osinubi and Eberemu, 2009; Eberemu, 2008).

Albrecht and Benson (2001) reported that volumetric shrinkage strain occurring in compacted natural clays during desiccation is a direct function of the volume of water/volume of soil when the soil 
was saturated. Soils with a higher clay content and higher plasticity index generally have a greater volume of water; thus they are more prone to large volumetric shrinkage strains during drying. In addition, specimens compacted close to the optimal water content with a higher compaction effort have less of a water/unit volume when saturated and lower volumetric shrinkage strains.

Problematic soils such as expansive soils (also known as black cotton soils) are normally encountered in foundation engineering designs for highways, embankments, retaining walls, backfills, covers, liners, etc. The mineralogy of this soil is dominated by the presence of montmorillonite, which is characterized by large volume changes from wet to dry seasons and vice versa.

Large quantities of waste materials from mineral, agricultural, domestic and industrial sources are generated daily, and the safe disposal of these wastes is increasingly becoming a major concern around the world (ETL, 1999). Metakaolin (MCL) is a pozzolanic material that is obtained by the calcination of kaolinitic clay at temperatures from 700 to $800^{\circ} \mathrm{C}$. The purpose of using metakaolin as an additive is to ensure that there will be enough pozzolan in the soil mixture to combine with the silica and alumina components of the black cotton soil in both short and long-term chemical reactions to form insoluble cementitious compounds made up of hydrated calcium silicate gel $(\mathrm{CSH})$ and calcium aluminate gel $(\mathrm{CAH})$. The study was aimed at an evaluation of desiccation-induced volumetric shrinkage of compacted MCL-treated black cotton soil as a suitable material for use in waste containment applications.

\section{MATERIALS AND METHODS}

\subsection{Materials}

Soil: The dark grey soil used in this study was obtained along the Gombe - Biu Road in the Yamatu Deba Local Government Area of the State of Gombe, Nigeria, using the disturbed sampling method. The location lies within the latitude of $10^{\circ} 19^{\prime} \mathrm{N}$ and the longitude of $11^{\circ} 30^{\prime} \mathrm{E}$. In terms of the extent of the deposit, black cotton soils are not restricted to the area of study but are widespread throughout northeastern Nigeria.

Metakaolin: The reddish brown metakaolin (MCL) used was obtained from freshly-deposited heaps of waste at a brick block production plant located in the Chukun Local Government Area of the state of Kaduna, Nigeria. The MCL has a specific gravity of 2.70. It was passed through a No. 200 sieve ( $75 \mu \mathrm{m}$ aperture) and stored in air-tight containers before usage. The specimens of MCL were sieved through a British Standard sieve after grinding. The portion passing through the sieve was compared to the required degree of fineness, i.e., 63 microns and below, while the MCL retained in the sieve was reground and sieved again. A chemical analysis of the MCL was carried out using an X-ray Analyzer together with an Atomic Absorption Spectrophotometer (AAS).

\subsection{Methods}

Index Properties: Laboratory tests were performed to determine the index properties of the natural soil and soil mixtures in accordance with British Standards BS 1377 (1990) and BS 1924 (1990), respectively.

Compaction: British Standard Light (BSL) and West African Standard (WAS) energies were used in tests involving the moisture density relationship and volumetric shrinkage. The air-dried soil samples passed through the BS sieve with a $4.76 \mathrm{~mm}$ aperture mixed with $0,4,8,12,16,20$ and $24 \%$ metakaolin by weight of dry soil
Tab. 1 Index Properties of the Natural Black Cotton Soil Used in the Study

\begin{tabular}{l|c}
\hline Property & Quantity \\
\hline Percentage passing BS No. 200 sieve & 87.0 \\
\hline Natural moisture content, \% & 15.0 \\
\hline Liquid limit, \% & 93.0 \\
\hline Plastic limit, \% & 21.0 \\
\hline Plasticity index, \% & 72.0 \\
\hline Linear shrinkage, \% & 21.0 \\
\hline Free swell, \% & 90.0 \\
\hline Specific gravity & 2.5 \\
\hline AASHTO classification & A-7-6 (16) \\
\hline USCS & CL \\
\hline NBRRI classification & High swell potential \\
\hline Maximum dry density, Mg/m ${ }^{3}$ & 1.41 \\
British Standard Light (Proctor) & 1.52 \\
\hline West African Standard & 30.6 \\
\hline Optimum moisture content, \% & 25.2 \\
British Standard Light (Proctor) & 7.2 \\
\hline West African Standard & Dark grey \\
\hline Ph & \\
\hline Colour & \\
\hline
\end{tabular}

were used. The British Standard Light is an effort derived from a 2.5 $\mathrm{kg}$ rammer falling through $30 \mathrm{~cm}$ onto three layers, each receiving 27 uniformly-distributed blows. The West African Standard (WAS) compactive effort was derived from a rammer of $4.5 \mathrm{~kg}$ mass falling through a height of $45 \mathrm{~cm}$ in a $1000 \mathrm{~cm}^{3}$ mould. The soil was compacted in five layers, each layer receiving 10 blows.

Volumetric shrinkage: The volumetric shrinkage upon drying was measured by extruding the cylindrical specimens, which were compacted using the BSL and WAS energy levels. The air dried soil - MCL mixtures were compacted at $-2,0,+2,+4$ and $+6 \%$ of the optimum moisture content (OMC). The extruded cylindrical specimens were placed on a laboratory bench at a uniform temperature of $25 \pm$ $2^{\circ} \mathrm{C}$ for 30 days to dry naturally because natural drying is considered as a simulation of field conditions. Measurements of the diameters and heights for each specimen were taken with the aid of a vernier caliper accurate to $0.05 \mathrm{~mm}$. The diameters and heights were used to compute the volumetric shrinkage strain.

\section{DISCUSSION OF RESULTS}

\subsection{Physical and Chemical Properties of the Materials Used}

Preliminary tests were conducted to identify and determine the properties of the natural soil. The test results are summarized in Table 1. The soil is classified under the A - 7-6 (16) subgroup of the AASHTO classification system (AASHTO, 1986) or CL in the unified Soil Classification System (USCE) (ASTM, 1992). The liquid limit and plasticity index values of 93 and $72 \%$, respectively, suggest that the soil is highly plastic. Thus, from the results obtained, the soil falls below the standard recommended for most geotechnical construction works (Butcher and Sailie, 1984). 
Tab. 2 Oxide Composition of the Metakaolin Used in the Study

\begin{tabular}{|l|l|l|l|l|l|l|l|}
\hline Oxide & $\mathrm{CaO}$ & $\mathrm{Al}_{2} \mathrm{O}_{3}$ & $\mathrm{SiO}_{2}$ & $\mathrm{Fe}_{2} \mathrm{O}_{3}$ & $\mathrm{Mn}_{2} \mathrm{O}_{3}$ & $\mathrm{Na}_{2} \mathrm{O}$ & $\mathrm{K}_{2} \mathrm{O}$ \\
\hline Concentration (\%) & 0.38 & 23.70 & 57.32 & 14.03 & 0.15 & 0.38 & 0.65 \\
\hline
\end{tabular}

The chemical composition of MCL is shown in Table 2. Based on its oxide composition the MCL used in this study falls into class $\mathrm{N}$ or $\mathrm{F}$ pozzolana in accordance with the provisions of ASTM C618 - 78 (1978).

\subsection{Compaction Characteristics}

\subsubsection{Maximum dry density}

The variations of the maximum dry density (MDD) with a metakaolin content are shown in Fig. 1. There was a general increase in MDD for the BSL compaction, while a decrease was recorded for the WAS compaction with an increase in the metakaolin content. The results are in agreement with the findings reported by Yoder and Witczak (1975).

\subsubsection{Optimum moisture content}

The variations of the maximum dry density (MDD) with a metakaolin content are shown in Fig. 2. The optimum moisture content (OMC) decreased and increased in the optimum moisture content at the energy level of the BSL and WAS compactions, respectively. The observed increase could be attributed to the increase in fine contents resulting from the inclusion of MCL with a larger surface area, which will lead to a greater demand for more moisture for the hydration reaction (Osinubi and Ijimdiya, 2008, Osinubi and Moses, 2012).

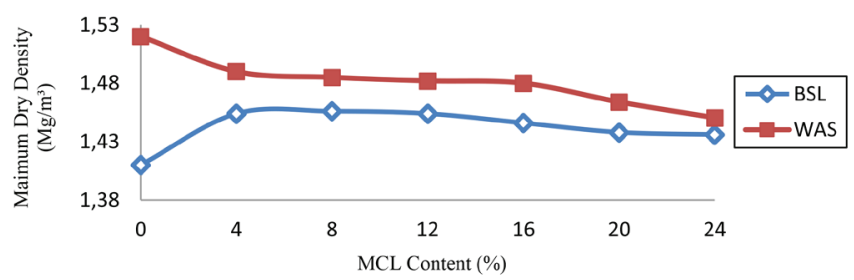

Fig. 1 Variations in the maximum dry density of the metakaolintreated black cotton soil

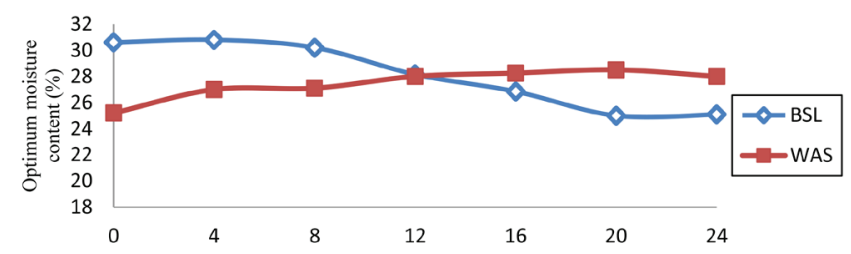

Fig. 2 Variations in the optimum moisture content of the metakaolintreated black cotton soil

\subsection{Volumetric Shrinkage Strain}

Basically, soil shrinks simply as a result of moisture loss, which is independent of the pressure, if the water and soil are considered incompressible. Daniel and Wu (1993) as well as Tay et al. (2001) suggested a safe volumetric shrinkage strain (VSS) value of less than or about $4 \%$ VSS upon drying for soil liners; when compacted, cylinders are used to predict field desiccation due to cracking. Low-density porous and wet soil has a tendency to shrink. This makes the soil

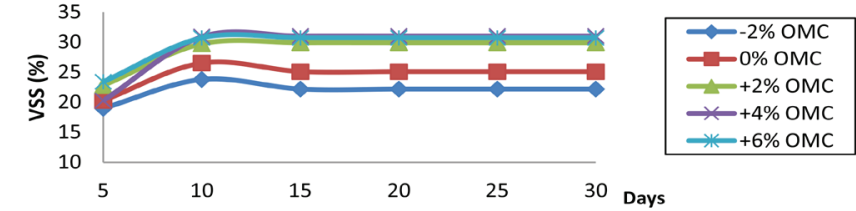

Variations in VSS with Days of Drying with Moisture Contents Relative to the Optimum for $0 \%$ MCL Treatment

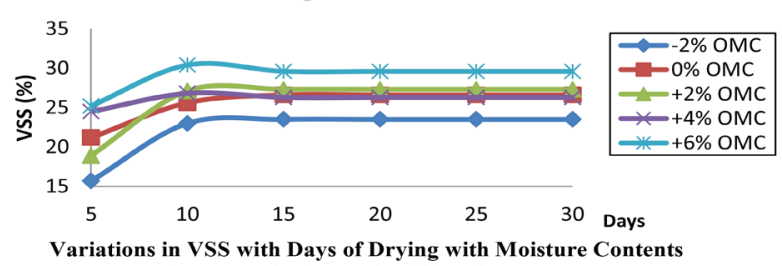

Variations in VSS with Days of Drying with Moisture Contents Relative to the Optimum for $4 \%$ MCL Treatment

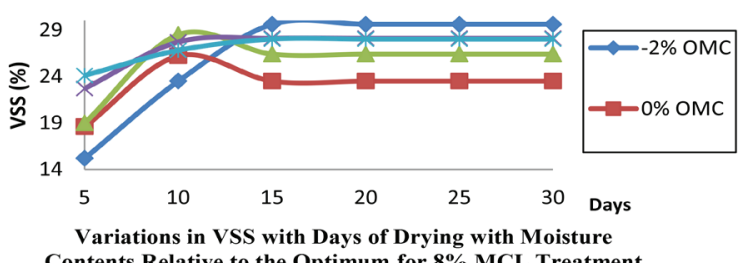

Contents Relative to the Optimum for $8 \%$ MCL Treatment

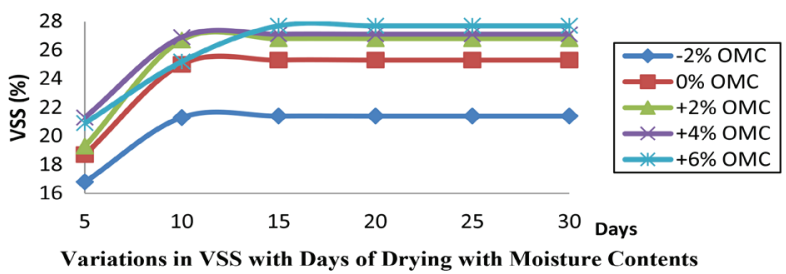
Relative to the Optimum for $12 \%$ MCL Treatment

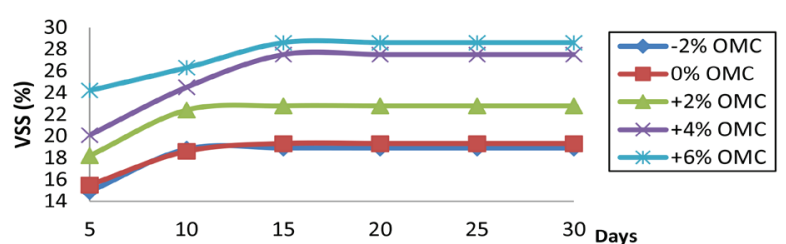

$\begin{array}{llllll}5 & 10 & 15 & 20 & 25 & 30 \text { Days }\end{array}$

Variations in VSS with Days of Drying with Moisture Contents Relative to the Optimum for $16 \%$ MCL Treatment
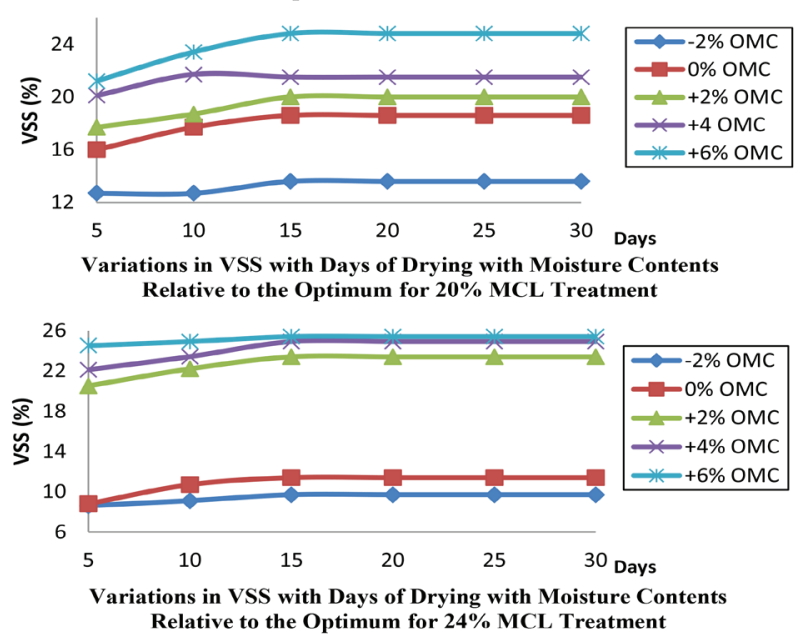

Fig. 3 Variations in the volumetric shrinkage of black cotton soilmetakaolin mixtures over time (BSL compaction) 


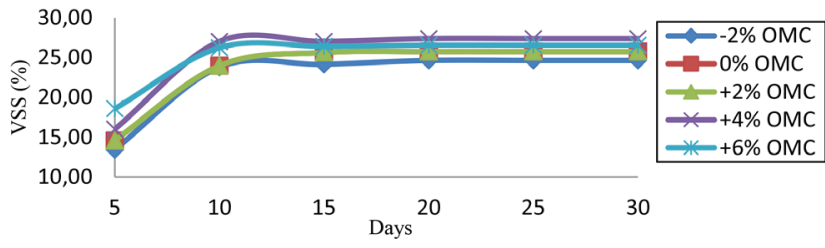

Variations in VSS with Days of Drying with Moisture Contents Relative to the Optimum for $0 \%$ MCL Treatment

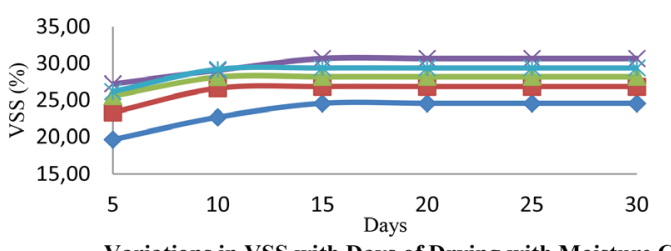

Variations in VSS with Days of Drying with Moisture Content Relative to the Optimum for 4\% MCL Treatment
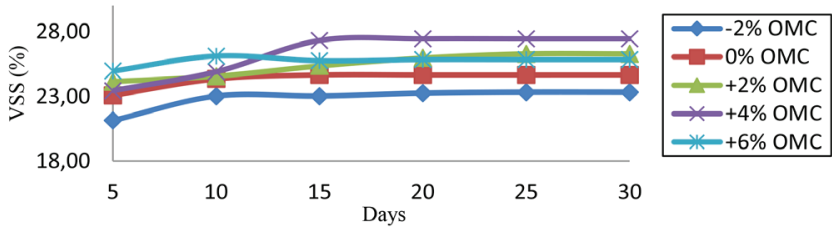

Variations in VSS with Days of Drying with Moisture Contents Relative to the Optimum for $8 \%$ MCL Treatment

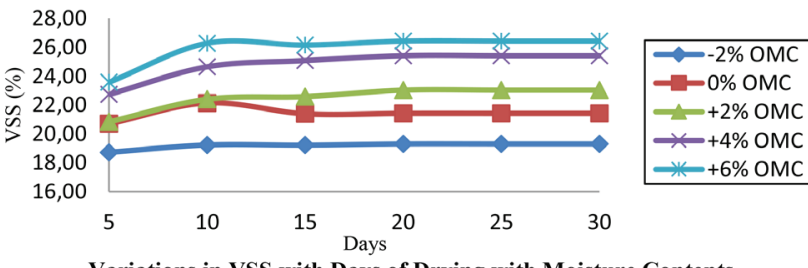

Variations in VSS with Days of Drying with Moisture Contents Relative to the Optimum for $12 \%$ MCL Treatment

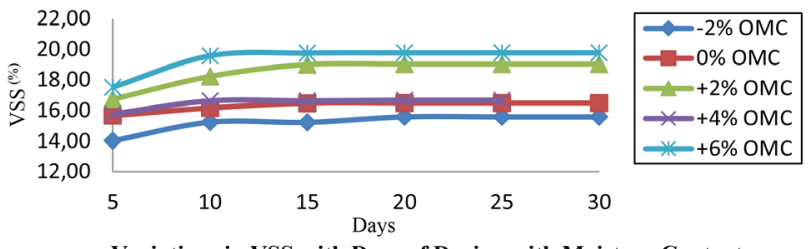

Variations in VSS with Days of Drying with Moisture Contents Relative to the Optimum for $16 \%$ MCL Treatment

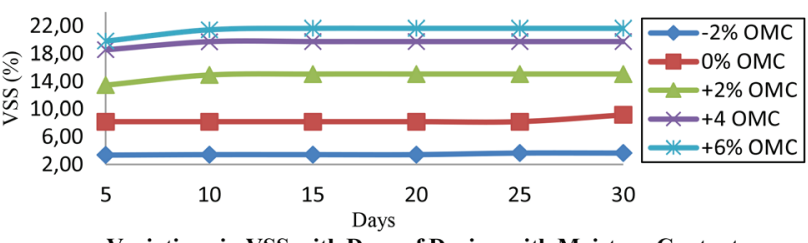

Variations in VSS with Days of Drying with Moisture Contents Relative to the Optimum for $20 \%$ MCL Treatment

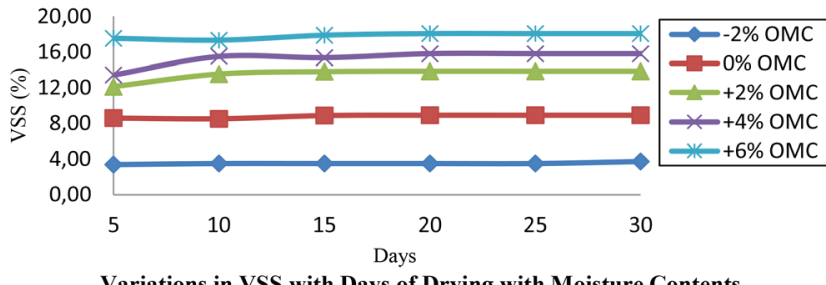

Variations in VSS with Days of Drying with Moisture Contents Relative to the Optimum for 24\% MCL Treatment

Fig. 4 Variations in the volumetric shrinkage of black cotton soilmetakaolin mixtures over time (WAS compaction) more readily prone to cracking, while highly dense and well-drained soil exhibits reduced shrinkage and a reduced risk of cracking.

The variations of the VSS black cotton-metakaolin mixtures (prepared at various moisture contents relative to the $\mathrm{OMC}$ ) over time are shown in Figs. 3 and 4. The natural black cotton soil compacted between -2 and $+6 \%$ of the OMC produced satisfactory volumetric strain values of less than $4 \%$ only for the WAS compaction. This can be attributed to the high clay content and high plasticity index of the natural soil as a greater volume of water was available and thus was more prone to large volumetric shrinkage strains during drying (Albrecht and Benson, 2001). Between the 4 and $24 \%$ MCL treatment there was a general decrease in the volumetric strain; this can be attributed to the pozzolanic input of the MCL, which reduced the high clay content in the soil with the formation of coarser fractions. However, satisfactory volumetric strain values were recorded only at the 20 and $24 \%$ MCL content.

Specimens compacted at a greater molding water content shrank more during drying, which is consistent with the results of Daniel and Wu (1993), Albrecht and Benson (2001). The reason is because according to Mitchell (1976), dry shrinkage in fine-grained soils depends on particle movements as a result of pore water tension developed by capillary menisci. Moreover, Albrecht and Benson (2001), Osinubi and Nwaiwu (2008) as well as Osinubi and Eberemu (2010), reported that the shrinkage strain depended on three main parameters: the molding water content, dry density (compactive effort), and soil plasticity index. If the plasticity index of the soil increases, the mold water content and the shrinkage strain increases. Furthermore, an increase in the compaction energy leads to an increase in the dry density and then a decrease in the shrinkage strain. Specimens compacted near the optimum water content with a higher compactive effort have a lower water/unit volume when saturated and lower volumetric shrinkage strains.

\subsection{Effect of the Initial Degree of Saturation on the Volumetric Shrinkage Strain}

The variations in the volumetric shrinkage strain of the black cotton soil-metakaolin mixtures with an initial degree of saturation are shown

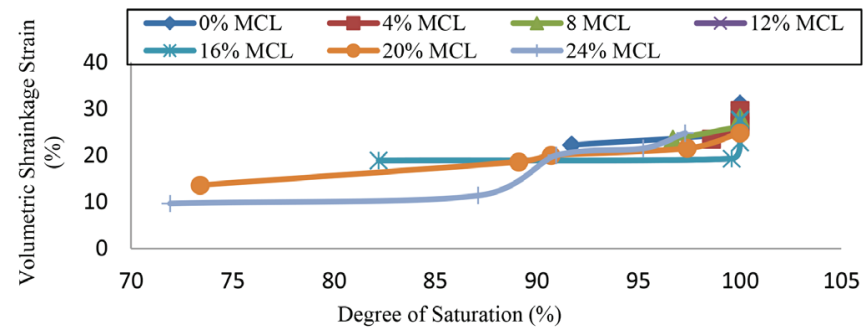

Fig. 5 Variations in the volumetric shrinkage strain of black cotton soil metakaolin mixtures with an initial degree of saturation (BSL compaction)

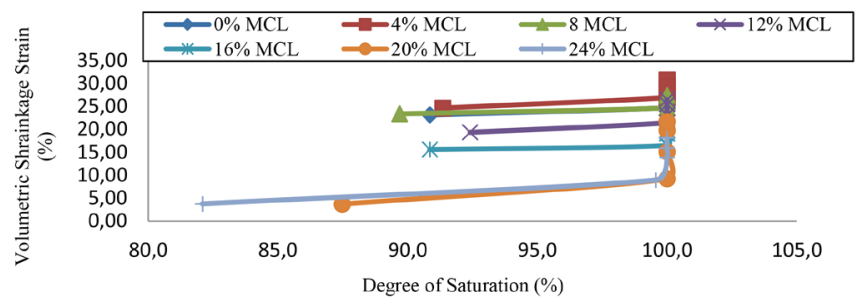

Fig. 6 Variations in the volumetric shrinkage strain of black cotton soil metakaolin mixtures with an initial degree of saturation (WAS compaction) 
in Figs. 5 and 6. The volumetric shrinkage strain generally increased with a higher initial degree of saturation, irrespective of the level of MCL treatment. Capillary tension developed since the particles were more flocculated, and it was relatively easier for particles to move due to the presence of more water in the soil as the degree of saturation increased. Only the specimens compacted with the WAS energy recorded satisfactory VSS values for the initial degree of saturation in the ranges of 82.1$83.5 \%$ and $86-87.5 \%$ for 20 and $24 \%$ MCL contents, respectively.

\section{CONCLUSION}

Laboratory tests were performed on black cotton treated with up to $24 \%$ metakaolin by dry weight of soil to assess its desiccation-in- duced volumetric shrinkage when used in liners and covers in waste containment systems. Specimens prepared with different molding water contents and compacted using British Standard Light (BSL) and West African Standard (WAS) energies recorded results that show an increase in volumetric shrinkage strain up to 10 days which remained fairly constant thereafter regardless of the compactive effort used. A satisfactory volumetric shrinkage strain (VSS) value of less than or about $4 \%$ was recorded only for black cotton soil treated with not less than a $20 \%$ metakaolin content and compacted with WAS energy.

This finding provides an economic means for the disposal of metakaolin waste and expands the scope of materials available for the treatment of black cotton soil for use in waste containment applications, especially in regions where it is impossible to avoid the use of such natural materials.

\section{REFERENCES}

AASHTO (1986) Standard specification for transportation materials and methods of sampling and testing, $14^{\text {th }} \mathrm{ed}$, Washington, D.C.

Abichou, T., Benson, C.H. and Edil, G. T. (2000) Foundry green sand as hydraulic barriers laboratory studies. Journal of Geotechnical and Geoenvironmental Engineering. ASCE, Vol. 126. pp. 1174-1183

Albrecht, B. A. and Benson, C. (2001) Effect of desiccation on compacted natural clay. Journal of Geotechnical and Geoenviromental Engineering., ASCE, Vol. 127, No. 1, pp. 67-75.

ASTM (1992) Annual book of ASTM standards, Vol. 04. 08, Philadephia.

ASTM C618-78 (1978) Specification for Fly Ash and Raw or Calcinated Natural Pozzolanas for Use as a Mineral Admixture in Portland Cement Concrete. American Society for Testing and Materials, Philadelphia.

Benson, C.H. and Albrecht, B.A. (2001) Effect of desiccation on compacted natural clays Journal of Geotechnical \& Geoenvironmental Engineering A.S.C.E., Vol. 27, No. 1, pp. 67-75.

BS 1377, 1990. Methods of Testing Soils for Civil Engineering Purposes. British Standard Institute, London.

BS 1924, (1990) Methods of Tests for Stabilized Soils. British Standard Institute, London.

Butcher, F.and Sailie, E. L. (1984) Swelling behaviour of tropical black clays. Proc. of the Eighth Reg. Conf. For Africa on Soil Mech. And Foundation Engineering, Harare, pp. 81-86.

Daniel, D. E. and Wu, Y. K. (1993) Compacted clay liners and cones for arid site. J. of Geotech. Eng'rg. ASCE. Vol. 119, No. 2. pp. 223-237.

Eberemu, O. A. (2008) Evaluation of compacted bagasse ash treated laterite soil as hydraulic barriers in waste containment systems. Unpublished Ph.D dissertation submitted to the Department of Civil Engineering, Ahmadu Bello University, Zaria.

ETL 1110-3-503, (1999) "Use of waste materials in pavement construction." Engineering Technical Letter, B-1 to B-22.

Mitchell, J. K. (1976) Fundamental of Soil Behaviour. John Wiley and Sons, Inc.

NBRRI, 1983. Engineering properties of black cotton soils of Nigeria and related pavement design. Nigerian Building and Road Research Institute, Research Paper Nos.1 - 20
Osinubi, K. J. and Nwaiwu, C.M.O. (2005) Hydraulic conductivity of compacted lateritic soils. Journal of Geotechnical and Geoenvironmental Engineering, American Society of Civil Engineers, Vol. 131, No. 8, pp. 1034-1041.

Osinubi, K. J. and Nwaiwu, C. M. (2006) Design of compacted lateritic soil liners and covers. Journal of Geotech and Geoenvironmental Engineering, ASCE Vol, No. 2, pp. 203-213.

Osinubi, K. J. and Eberemu, A. O. (2006) Hydraulic conductivity of lateritic soils treated with blast furnace slag. Electronic Journal of Geotechnical Engineering. EJGE, Vol. 11. Bundle D, pp. 1-21.

Osinubi, K. J. and Nwaiwu, C. M. O. (2008) Desiccation-induced Shrinkage in Uncompacted Lateritic Soils. Journal of Geotechnical and Geological Engineering, GEGE, Springer, Netherlands, Vol. 26, pp. 603-611

Osinubi, K. J. and Ijimdya, T. S. (2008) Laboratory investigation of engineering use of bagasse ash. Nigerian Society of Engineers Technical Transactions, Vol. 43, No. 1, pp. 1-17.

Osinubi, K. J., Eberemu, A. O. (2009) Desiccation-induced shrinkage of compacted lateritic soil treated with bagasse ash. The Twenty-Fourth International Conference on Solid Waste Technology and Management CD-ROM, 15-18 March, Philadelphia, PA, U.S.A. Session 5C:Bio-reactors and Innovative Landfills, pp. 856-867.

Osinubi, K. J. and Amadi, A. A. (2009) Hydraulic Performance of Compacted Lateritic Soil Bentonite Mixtures Permeated with Municipal Solid Waste Landfill Leachete. Transportation Research Board (TRB) 88 Annual Meeting CD-ROM 11-15 Jan, Washington DC, U.S.A. Subject. Geology and Earth Materials, Session APP40-Physico-Chemical and Biological Process in Soils Committee, Paper 409-0620, pp. 1-18.

Osinubi, K.J. Eberemu, A.O. (2010) Desiccation induced shrinkage in compacted laterite soil treated with blast furnace slag. Journal of Geotechnical and Geological Engineering, Springer, the Netherlands, Vol. 28, pp. 537-547

Tay Y.Y., Stewart D.J., Counsins TW (2001) Shrinkage and dessication cracking in bentonite - sand landfill liners. Eng Geol 60:263-274

Yoder, E.J. and Witczak, M.W. (1975) Principles of Pavement Design. John Wiley and Sons. Inc. New York, pp. 300-321. 